Article

\title{
Sustainable Urban Tourism: Reflections on the Need for Building-Related Indicators
}

\author{
Antonella Lerario * and Silvia Di Turi \\ Construction Technologies Institute-National Research Council of Italy, 70124 Bari, Italy; silvia.dituri@itc.cnr.it \\ * Correspondence: antonella.lerario@itc.cnr.it; Tel.: +39-080-5481265
}

Received: 7 May 2018; Accepted: 11 June 2018; Published: 13 June 2018

\begin{abstract}
A solid and consistent research production has, up to now, considerably contributed to the identification and exploration of the meanings, theoretical foundations, and possible implications of tourism in the cities. The focus on pursuing sustainable tourism activities has also inspired different approaches (eco-tourism, responsible tourism, pro-poor tourism, among others). Nevertheless, difficulties still exist in the definition of concrete solutions to the complex problem of how to activate and facilitate the diffusion of sustainable urban tourism practices. Given the central role of indicators in the monitoring of transformation and defining impact mitigation measures, this article proposes an unexplored interpretation of such tools, which are specific for the built environment as a main component of the urban context. Starting from a broad examination of the literature on urban tourism and its related impacts, and focusing on heritage destinations, the authors highlight the potential of the built environment to play an active role in reducing the extent of potential flow impacts upstream of their actual occurrence. As a result, possible building-scale indicators that could integrate current downstream evaluation and mitigation practices are identified and suggested, and their possible implications are discussed alongside those of existing indicators. Finally, further developments for future research are suggested.
\end{abstract}

Keywords: sustainable urban tourism; urban tourism impacts; built environment; carrying capability; building-related indicators

\section{Introduction}

Today, mass tourism is one of the most widespread problems in large and small cities, and particularly in heritage tourism destinations.

Since the 1960s-1970s [1], the globalization of tourism has brought ease to travel, as well as a wider and wider variety of users who go out to discover the cultural aspect of the cities, which are now accessible by ordinary people in part thanks to smart apps and the Internet. All of these phenomena have led to the increase of problems that local stakeholders cannot adequately manage at present in all of their social, economic and environmental respects.

Defining "sustainable" tourism is difficult, as it has taken on increasingly diversified facets, and hardly fits into a broad and complete framework, even for scholars [1-3]. Furthermore, relating this concept to the dimension of sustainable cities is even more challenging: is it essential to consider tourism as an independent driving force with the connotations of sustainability in itself, or does its control mean giving it the appearance of a tool for achieving sustainability in the broader context of the city? Even more so, it becomes difficult to define the role that architectural and artistic assets hold as main attractions in urban cultural tourism: on the one hand, they are real resources to be protected and preserved; on the other hand, they become the main economic channel's profit, representing a dichotomy within the concept of sustainability. 
In a considerable portion of the literature, it can be drawn that despite academic efforts in the theorization of sustainable tourism and the analysis of its different implications, difficulties still exist in the diffusion of practical solutions and achievements, and that reframing basic concepts is necessary to fill this gap $[1,2,4,5]$.

An important point is represented by the necessity to rely on indicators that are specific for sustainable urban tourism, which are needed for the description of different contexts and as tools for decision-making. Actually, several sets of indicators have been elaborated in the fields of sustainable urban development and sustainable tourism, as well as for sustainable heritage (heritage being the main tangible component of cities and the main driver of urban tourism). Nevertheless, clear references for sustainable urban tourism are still missing.

The following paragraphs present, firstly, a literature review on the expression "sustainable urban tourism", which is meant as a confluence point of different conceptual components. The used methodology starts from the analysis of sustainable tourism in a general way, and then explores the idea of sustainable cities, and finally how they converge in urban dynamic processes with their more or less sustainable implications. Broad attention has been paid to highlighting the major aspects that characterize two different dimensions: the need to combine tourism and the city in sustainability, and at the same time how cultural tourism can be a link between these two. Secondly, an overview of the consequences of this complexity at the evaluation level is provided, and some gaps that exist in current sets of indicators in relation to the built environment are highlighted. Thirdly, this article presents a new approach to the problem, based on a systematization of the possible impacts that are relevant for the built environment, both in general and for single buildings, and on a change in perspective in the consideration of cities' attitudes and potential toward tourism-induced effects. Then, the authors suggest a re-sizing of the observation scale for indicator-related issues, and propose possible building-scale indicators in order to integrate current downstream evaluation and mitigation practices as well as existing indicators, discussing their possible implications. Finally, further developments for future research are suggested.

\section{Tourism and Cities in the Light of Sustainability}

In general, the idea of sustainable tourism was born in contrast to the mass tourism that only began to emerge in all of its negative impacts at the end of the 1980s [3,6]. In its sustainable tourism definition, the World Tourism Organization [7] outlines the current and future needs of tourists as well as the host community, and at the same time takes into account the social, economic, and environmental aspects. In order to achieve sustainability, a continuous process of monitoring impacts and implementing preventive and corrective measures is required; it is also key to involve tourists firsthand in this process, so that they become aware and can implement good practices.

In fact, the tourist is the first involved social actor that influences the success and evolution of the destination as it becomes more and more experienced; the tourist is both critical and conscious of quality [8]. Tourists look for new experiences, but at the same time also demand a good compromise in economic terms. For this reason, competitiveness among the various tourist destinations is increasing [6].

Contrary to the expression "sustainable development", which notoriously implies growth in the various considered areas, "sustainable tourism" indicates, instead, a much more general process that does not necessarily include growth, and implies dynamics such as the stabilization, increase, reduction, and change of multiple elements [1,9].

Saarinen [1] highlighted how the several definitions of sustainable tourism over time have sometimes been even contradictory, focusing separately on the interests of industry or on the sustainable use of resources. The pillars of sustainability (social, economic, and ecological) are no longer on the same level, but the aspect of economic interests prevails, as tourism becomes the driving force of the local economy. Moreover, the "global" dimension of the term "sustainable" is missing, as it focuses on single destinations and an analysis of the local context, neglecting the existing network of 
relationships and infrastructures. Examples include the long journeys that tourists face in order to reach the designated destination, and thus contribute to pollution and climate change [4]. Little attention is given to the impact of tourism in environmental terms, compared with the focus on economic factors and interests, as tourism becomes the driving force of the local economy. Everything is done according to a strategic business plan in which the market, as well as the needs and expectations of tourists, are the core of tourism planning. In this situation, residents are not so important $[10,11]$. On the contrary, residents ought to have a respectable role in terms of planning in the sector [2], and they should not be involved sporadically, as in the classic approaches to sustainable tourism implementation. Moscardo and Murphy [4] emphasize this concept by reaffirming that the key stakeholders are all those who must live and cope with the effects of tourism, and that the impacts of tourism itself go well beyond the single destination, but develop in many dimensions and different fields. Therefore, residents must take an active part in the planning process, rather than simply be informed [12].

The definition of sustainable tourism has often included sub-categories such as the more specific forms of "ecotourism" and "responsible tourism", which were both characterized by an environmental awareness.

The term "ecotourism" has been much debated in the academic field [13]. Blangy and Wood [14] defined it as "responsible travel to natural areas that conserves the environment and sustains the well-being of local people" [15]. The mentioned definition already has the dichotomous problem of the conservation of natural resources when tourists arrive. The original uncontaminated natural areas are instantaneously transformed, adopting the basic infrastructure for welcoming tourists, which breaks the equilibrium between the environment and people with different lifestyles and their respective opposite forces [15].

On the other hand, "responsible tourism" aims at developing principles and practices that make places better both for the resident's quality life [16-19] and for the quality of the tourist's visit. It is achieved by minimizing the negative aspects and maximizing the positive ones from all points of view (social, economic, environmental) in the destination communities, promoting an ethics in consumption and production by all stakeholders [1]. This definition is therefore comparable to the more general one of sustainable tourism [20].

However, very often, tourism is considered as a strictly independent activity and sector without considering what its development causes in other sectors, or the growth dynamics of a city [11,21].

Indeed, cities are themselves dynamic and constantly evolving systems that lead to an immense consumption of resources of all kinds. The increasing urbanization is leading to the creation of megacities. It has been predicted that about $60 \%$ of the population will live in cities and urban areas by 2030 [22]. In light of these transformations, sustainability is essential to control their development and, above all, contain the negative impacts that inevitably derive from them. This objective is increasingly being identified with energy consumption reductions. It focuses, for example, on the construction and upgrading of buildings with integrated and decentralized energy production systems in order to constitute entire self-sufficient district areas with zero emissions [23]. Water collection technologies, for example, make it possible to safeguard huge reserves of water, which is currently one of the most widespread problems in the world. The optimized management of waste with disposal and treatment systems and buildings' energy-efficiency are all essential aspects that start from the architectural scale, but affect the urban "metabolism", as amply demonstrated [24,25]. Integrated sustainable infrastructures and the creation of synergistic behaviors between the different sectors can significantly reduce the exploitation of resources, especially energy, food, and water. In this way, it is possible to create a circular flow in the economy of the city development processes through the decentralization, active participation, and intelligent use of resources. Furthermore, investment, service, and maintenance costs are reduced, and environmental protection and resource conservation increase [23]. To contribute to the sustainability of the city, especially in environmental field, there is not only the built heritage, but also the transport sector, which affects $14 \%$ of global greenhouse gas emissions [26]. Multi-modal and low-carbon transports can contribute positively in terms of air 
quality, traffic congestion, safety, and general social mobility and, therefore provide a higher level of socioeconomic benefits, in addition to lower costs $[27,28]$. This is also inevitably reflected in the tourism sector, which in large part contributes to the growth in the demand for fast and optimized public transport from all points of view. Sustainability also invests all of the dynamic processes of a city-the economic, the social, and the environmental-from the protection of natural, cultural, and architectural resources, to the collection of waste [24,29-33].

Urban tourism is a complex phenomenon to define, which has challenged many scholars. It is undoubtedly more complex than simply "tourism performed in the cities" rather than in other sites, and it is not conceptually homogeneous to expressions such as "sea tourism" or "rural tourism". Some researchers individuate urban tourism complexity in its multifunctional character [34,35], in its articulation in "microdestinations" [36], and in its dense coexistence of built forms, structures, and cultures [37]. In particular, the term "urban tourism" can be considered almost as defining a category, in which cultural tourism, conference tourism, sports tourism, and many others can all be regarded as possible "urban tourisms".

The size of cities further articulates and differentiates urban tourism features, leading to the possibility of analyzing specific issues of tourism or cities' responsiveness to it, respectively for small and large cities [38-41] or focusing on tourism in capitals [42].

Moreover, urban tourism is marked by specific peculiarities [34,43], such as: rapidity (shortness of stays), repetition of visits (greater for cities perceived as the representation of a given "way of life", lesser for cities with single well-known "attractions" or "must-see"), or "capriciousness" (requiring cities' ability to reinvent themselves in order to match the ever-changing desires of visitors). Similarly, a distinction can be made between proper "urban tourists" (whose reason for the visit is linked to some facet of this urban complexity) and "tourists in cities" (whose motivations are independent from the place). On the other hand, it is often impossible to distinguish the spaces and resources used by tourists from those used by inhabitants [34].

Given this conceptual complexity, many approaches to urban tourism have been developed, such as the systemic approach [35], "microscale" approaches based on the identification of microgeographies and microdestinations [34,36], or "micro-macro" approach [3]. In particular, the systemic approach focuses on the concept of urban entropy as diametrically opposed to sustainability, and of tourism as a phenomenon that is able to cause it to increase by bringing about unbalances among urban functions and consequences such as congestion, overcrowding, inhabitants' displacements, partial or total urban ousting, and general conflicts in the use of urban spaces and resources. The "microscale" approach promotes the substitution of administrative borders through smaller geographical units that have their own images, tourism identities, and typologies for destination management. Lastly, the "micro-macro" approach suggests the integration of the "macro" principles of sustainability in tourism with the consideration of local unbalances and justice-related issues. These well-established approaches are examined in depth in the following paragraphs.

At the level of impacts, the twofold nature of urban tourism, due to its ability to potentially bring about social and economic benefits to a destination but also deteriorate its environmental and physical resources, has been acknowledged and stressed diffusely [44-46].

One major component of urban tourism is represented by cultural heritage tourism, since it is the fastest-growing sector within the overall tourism sector (cultural tourism doubled its volume in number of trips between 1995-2012 [47]), and it mostly develops within cities. It represents a perfect example of what is defined as "tourism paradox", i.e., the tendency of the tourism activity to exhaust the same resources that it needs to feed itself [45].

\subsection{Cultural Tourism in Urban Dynamics}

In this context, tourism represents a highly impacting sector, as it determines the uncontrolled growth of the city and the intensive exploitation not only of environmental, social, and economic resources, but also of architectural heritage. This particular type of resource, of historical and artistic 
value that has survived over historical periods and is not free from transformations and alterations, is often neglected.

Surely, cultural tourism is based on the identity and originality of the local context and region [48], and has the potential to transform this heritage into additional value that the local community can benefit from without damaging the monuments. Tourism, in fact, contributes to the increasing living standards of residents and all those who actively participate in these activities, and makes people proud of their cultural resources. Sustainable cultural tourism aims at the conservation, development, and maintenance of natural, historical, cultural, social, and aesthetic values in a network that is close and interconnected to the economic and physical growth of the city. However, the two aspects of conservation and economic growth are conflicting forces that push in one direction or another, and prevail depending on the situation [49]. It is almost never easy to establish a balance between cultural value and the desire for profit.

As Russo [50] highlights, the development dynamics of tourism in cities with cultural heritage can become highly unsustainable. The author describes a "vicious circle" of tourism development that is divided into different phases. In the first step, the city attracts the so-called "pioneers", which are the first tourists who come attracted by local resources and are generally gifted with culture and sensitivity to the beautiful. If the city later becomes a known destination and increases stays, including overnight accommodation, investments in infrastructure, services, and advertising begin. The city then begins to develop intensively, with initially large tangible and intangible benefits that drastically increase and stimulate the local economy. In the maturity phase, the industrial organization of tourism changes and non-local actors, such as organizations and promoters of tourism activities, end up dominating the production of goods and services, regardless of the local population. At this point, the phases of stagnation and decline begin.

An inexorable decline can follow the uncontrolled development of this activity, as costs increase and the entire economic sector is put into crisis.

It is important to also understand the type of tourist who is attracted to the city, which influences urban dynamics. Both the absolute number of tourists and the mix of the various types of activities and buildings in the area affect the associated costs and benefits.

The negative effects of unconditional development both determine and go hand in hand with the enlargement of the tourist region and, above all, with the appearance of the so-called "false hikers", i.e., tourists who choose a peripheral cheaper site to save money and overcome the problem of limited accommodation availability near the main destinations. In the center, costs increase and benefit-sharing decreases, originating rivalry on the regional scale between the center and neighboring communities.

The city's administrative bodies must impose higher taxes to maintain the higher budget that is required for cultural heritage conservation, city cleanliness, and trade.

In the end, the preservation and trade of cultural endowments require external funding, special laws, and government transfers, exacerbating the rigidity of the tourism policies' application field. Simultaneously, if the industry strongly enhances tourism, it neglects the weakest economic sectors of the city $[50,51]$. The destination loses its other productive activities, going toward a possible failure of the local industry, and removing the typical functional mix of a sustainable city.

The tourist region undergoes expansion beyond the city center, primarily due to the growth in demand suffering from a fluctuating trend.

The excessive tourism growth causes firstly the overload of facilities in the center. Resources (territory, buildings, roads, parking lots, etc.) near the central attractions are limited, but continue to be exploited. Once saturation is reached, part of the complementary industry disperses, especially because centrality becomes more and more expensive (recreational areas, new hotels, transport terminals). Meanwhile, the tourist activity remains localized in the central district, which hosts both cultural attractions and services for tourists. 


\section{Approaches for the Evaluation of Sustainable Tourism in the Urban Environment}

Many researchers and tourism associations have looked for ways to establish a limit or threshold for tourism growth through identifying sustainable development indicators and carrying capacity [1]; however, they have had limited success [6]. Furthermore, the resources available for tourism are divided into attractive, infrastructural, and context resources. Obviously, the landscape and natural resources are considered unlimited (if there is an adequate protection policy), while the other resources are subject not only to the tourist demand, but also to the management of the phenomenon, influencing its development. They are not resources in the absolute sense, but they become resources when a certain policy adopts them for the development of tourism itself.

Liu [6] advised a "safe minimum standard" approach to avoid irreversible changes that preclude development opportunities for future generations. The concept of "carrying capacity" is also very important, and is a key concept for tourism that requires adequate planning and operational control. According to this idea, fixed and determined limits to development exist, and are not always easy to define. Generally, in the tourist sector, this threshold refers to the maximum number of visitors that an area can accept without excessive negative impacts, environment degradation, and decline in tourists' satisfaction [50-52]. It is difficult to calculate this threshold, as it depends on the type of the destination with its various life cycle steps and the kind of offered products and attracted tourists. In addition, the concept of carrying capacity covers various aspects, including physical (maximum number of tourists, which relates to the minimum space needed by each tourist), ecological (impact of tourism on resources), psychological (perception and satisfaction of tourists, depending on the type of vacation and destination), social (tourism impact on host community), and economic (profit costs and opportunity) ones.

In the approach of the vicious circle of tourism [50], as previously described, costs and benefits are spatially distributed, depending on each phase of the destination's life cycle. Firstly, benefits extend to the destination area. Subsequently, the incomes from tourism spread into the regional territory, while the costs remain localized in the attractive area, until they start to weigh on the entire local context in the phase of decline. The link between spatial expansion and economic dynamics highlights the role of tourism development modalities in the origin of stagnation. The intensive and uncontrolled, and therefore unsustainable exploitation, the so-called "tourismification", leads inexorably to the decline of the tourist destination.

The challenge is to keep the flows below the threshold of carrying capacity [53,54], and achieve a balanced relationship between the costs and benefits from tourism.

Moreover, the quality of the experience of visiting monuments while having fun decreases with the physical stress imposed by tourism and the decline in the quality of the environment and auxiliary infrastructures.

Cultural heritage in cities is generally not widespread enough to spread tourism across a large base of resources. On the other hand, it is not concentrated enough to constitute an autonomous and limited "museum-city" structure. Thus, growth constitutes a threat for other urban functions [50].

The rate of tourist growth for a major cultural destination always persists to a certain degree as new markets and a new target of tourist groups develop continuously, and people travel easily thanks to technological and economic progress. Consequently, the adopted policies should be anticipatory and proactive, and they should level the fluctuations of this process [50].

Without redistributive policies, the social costs deriving from tourism will weigh on residents. Thus, the vicious circle will cause a reduction in the attractiveness of the central area, the quality of content, and accessibility. In this situation, the peculiarity of the contexts can have a great influence.

In many cases, the "carrying capacity" can be exceeded. The tourist pressure deriving from mass tourism causes tension between tourism stakeholders and the local population [50].

The carrying capacity and the visitor impacts are also influenced by the tourist's behavior and practices, as well as by the resilience of the physical and socioeconomic environments of the destination. 
It is hence closely related to the so-called "original non-tourism conditions", which are not always easy to evaluate $[55,56]$.

There is no intrinsic or innate carrying capacity of the place, a "magic number" [1] that defines a certain space and a certain period of time, and creates a limit threshold beyond which serious damage will be created $[57,58]$. An area may have many carrying capacities depending on its characteristics and values; this is a key concept in the development of tourism management [59]. Moreover, as tourists begin to use the area, their presence alone has an impact, independently of their quantity. The reduction of visitors on already exploited areas could have particularly dramatic consequences before obtaining an effective mitigation of the impacts. Finally, once the impacts become dramatic and severe, it can be difficult to implement mitigation strategies and achieve the desired results. On the one hand, there is the need to control and solve the damage already done; on the other hand, there is a substantial need to predict the possible consequences of tourism exploitation.

Furthermore, it is difficult if not impossible to achieve a single carrying capacity index. There are multiple points of view and perceptions both in tourists, depending on the expectations, that they have towards the destination, and in the residents, who may be more or less favorable to tourist presence depending on economic interests (whether or not they are operators in the tourism sector) and social and biophysical aspects [59]. It was shown that approaches seeking to obtain a numerical value of carrying capacity have failed in determining how to control, reduce, and mitigate impacts. They are, in fact, a function of the tourists' behavior, as well as organizational practices and other variables that are closely linked to the specificity of the contexts and their dynamism. Impacts or damages can be reduced much more effectively by acting on and trying to change tourists' behavior or management practices, rather than limiting use and tourist flows to the destination.

It is essential to be critical of the concepts of sustainable tourism and impact assessment to provide a different view of the evaluation methods that have been addressed and proposed in the existing literature.

Liu [6] discussed macro and micro approaches: the former takes into account the resources and environmental balance to measure the conditions of sustainability; the latter highlights the cost-benefit analysis. The macro approach highlights the importance of irreversibility, while the micro approach substitutes natural components with anthropic ones. Which of the two approaches is the most right, and has to be maximized? Should a destination safeguard its natural untouched assets, or become a tourist attraction and, through tourism, increase the technological and infrastructural capital by accepting limited changes in the natural environment? This is a concept that is transferable to cultural tourism in cities. Is it right to put cities in such conditions as to transform them into a single tourist vocation and make everything revolve around this activity? Or, in another way, is it right to preserve the identity character that is dictated not only by culture and tradition, but also by the historical built heritage? The architectural monuments are too often used only for visits and exhibitions, and become pressed by a constant tourist flow that makes them lose their intrinsic meaning (just think of churches, within which areas of prayer need to be circumscribed, although this was the primary activity for which these places were designed). Too often, cultural building heritage sustains huge impacts not only from economic and social points of view, but also from environmental and technological ones, since real physical damage occurs. It is certainly necessary to maintain a balance between consumption, transformation, and the creation of resources for tourism.

The concept of resource conservation is an issue in and of itself. Zeayter et al. [60] emphasized the different ideologies of "conservation" of cultural heritage, in particular considering "conservation" as a multidisciplinary practice involving environment, art, architecture, and archeology.

The control of tourism flows is included widely in contemporary conservation approaches that must take into account a balance between public, private, and European Union (EU) investment. It has to assume responsibility for the conservation of cultural heritage and ensure the optimal management of resources and sustainable development. Among these approaches, the following described are some of the most significant in terms of the relationships and connections between cultural heritage 
and urban dynamics. The selected ones are illustrated in order to consider the intertwined roles of attractive sites and built environment in tourist cities, and their implications.

The Culture Tourism approach focuses on the importance of well-organized and managed sites within a sustainable framework that protects the asset and respects the host communities.

At the urban level, conservation is obviously linked to planning processes, but with tourism development, it assumes a commercial dimension, i.e., the "product-led dimension" [60,61].

According to the Living Heritage approach of the International Centre for the Study of the Preservation and Restoration of Cultural property (ICCROM), the importance of cultural heritage is found both in physical features and the ways in which society evaluates cultural heritage and uses its potential.

According to the Historic Urban Landscape (HUL) approach, urban heritage acts as a stimulus for socioeconomic development through tourism, trade, and the high value of land and property, beyond the cost of maintenance, restoration, and recovery.

The HUL connects tangible and intangible parts, and considers the dynamic nature of urban areas that are in a continuous process of change.

The integration of urban heritage values into the wider framework of city development requires greater attention to the planning, design, and implementation of development projects, and also considers the high sensitivity of these contexts. The HUL takes all aspects together: the preservation of natural resources, archaeological sites and historical factors; economic pressures; gentrification; building pathology; and both tangible and intangible values.

Often, institutions committed to heritage preservation adopt the HUL approach. Some observations should be made that reference the institutional approach. The introduction of instruments conceived for preservation purposes, such as, above all, the inscription of cultural resources and specifically tangible assets (buildings, monuments, or ancient town centers) in the UNESCO World Heritage List (WHL) are currently stimulating the international debate. Many articles have questioned whether the designation in fact represents a real advantage or is rather, a burden for destinations, what its concrete effects are in terms of tourism increases, and whether that increase is consistent or compatible with the general sustainability goals of the destinations and their local communities [62-68]. Based on the limitations of current WHL role formulation (undermined credibility due to unbalance in the assets' geographical distribution, an excessive number of designations, difficult management of serial and transboundary resources, the limited control and sanction powers of UNESCO, poor financial resources for the protection of too many sites), and the lack of quantification regarding changes in actual tourist numbers, it is concluded that it is at least a mixed blessing, or in simple terms, a double-edged sword. Commonalities in case study results suggest that any designation ought to be considered an opportunity and a starting point, rather than a goal achieved toward a site's development; as a consequence, appropriate planning patterns need to be subsequently arranged. There is a need to protect historic sites from the impact of new global challenges, including climate change, urbanization, and the pressure of unsustainable tourism [60].

Among the basic criteria for inscription in the World Heritage List, cultural quality considerations, and specifically the ascertained Outstanding Universal Value obviously plays a preeminent role. The ultimate goal of sites' preservation motivated UNESCO to elaborate tools that substantially focus on tourists' behaviors and ways to raise awareness and redirect practices toward sustainability, such as the Tourism Checklist (while we are waiting for the announced tool for the self-assessment of tourism sustainability levels, which is intended for destination managers). Meanwhile, tools for a sustainability-related quality assessment that is tailored for the built environment are still missing. 


\section{4. "Upstream" and "Downstream" Indicators for Sustainable Urban Tourism Practices: Proposals and Discussion}

\subsection{Traditional Indicators in the Field of Sustainable Tourism}

In this context, tourism represents a highly impacting sector, as it determines the uncontrolled growth of the city and the intensive exploitation not only of environmental, social, and economic resources, but also of architectural heritage. This particular type of resource is of historical and artistic value, survived over historical periods, is not free from transformations and alterations, and is often neglected.

In view of all of the approaches described, it is not easy to define a single methodology for assessing the sustainability threshold of cultural tourism, as many aspects contribute to it.

Undoubtedly, considering all of them leads to a huge effort by researchers and involved stakeholders, because they have to take into account the three specific fields of sustainability: the economy, society, and the environment. Moreover, it is necessary to define them in detail in order to identify the standardized categories that allow for a simple quantification of the desired levels, and divide them in more describable and analyzable features through indicators in order to provide a method of scientific evaluation for a multi-faceted issue.

Many studies [69,70] have attempted to list the indicators identified by various research works $[71,72]$ in the field, even defining more than 500 indicators that might be useful for assessing the sustainability of the tourism sector. They tried to create "composite" indicators $[69,73]$ that could provide more immediate methods of evaluation, and improve the usability of the analysis in order to implement strategies for rising sustainability levels. One of the main objectives of these works is to reduce the analyzed categories; thus, they choose some weighting systems to be attributed to the indicators [74] in order to obtain more streamlined evaluations that are easy to be consulted in decision processes.

Regarding the social field, tourism in general includes some main stakeholders with different fundamental roles in its dynamic processes: tourists, government organizations, destination management organizations, tourism operators, and last but not least, residents. Therefore, each of them must actively participate, so that tourism development is effectively sustainable, seeking mediation between the interests of each social group. The multiplicity of aspects within this field makes it difficult to define the indicators. Categories for the assessment of social aspects can include: the public services available and allocated to tourists, the sense of security and preservation of the cultural heritage of tourist destinations, and the problems related to preserving the "quality of life" of residents, such as ensuring a balanced distribution of services and the preservation of local identity and habits [69]. The latter are especially important, since they become part of a process of globalization favored by flows of people entering and living, or sociocultural aspects. As an objective of these indicators, it is important to define whether the "quality of life" is respected or maintained [75,76]; this concept represents the cornerstone of all social and economic considerations, and goes far beyond the tourism sector boundary.

With regard to the economic field, it is obvious that this component is a driving force in the tourism sector. Beyond reflecting on the need to balance revenues and limit tourist flows in favor of the quality of residents' lives and asset use, these needs often find themselves in contrast with the dynamics of profit triggered in destinations of great attraction. However, the main categories of the assessment of sustainability in the economic field refer to the direct and indirect benefits of tourism that are obtained through visitor satisfaction and the duration of market demand over time.

In the environmental field, the main problems are the loss of renewable and non-renewable resources over time, the degradation rate of ecosystems, the environmental impacts of tourism, the rate of reuse and recycling, and the health of the human population [77]. These issues include energy consumption, water use and saving, as well as rainwater reuse, polluting emissions, noise level, visual pollution, and all of the things that can compromise natural and historical sites. The intent 
should be to achieve a "harmony with nature" [78], in a perfect balance between strongly impacting anthropic activities and the environment.

Lozano-Oyola et al. [73] exposed their method for the evaluation of sustainable tourism using significant indicators, and defined the basic aspects that ought to be referred to for a complete analysis of sustainability level for tourism in cultural destinations, as summarized in Table 1.

Table 1. Traditional tourism aspects for indicators definition (based on Lozano-Oyola et al. [73]).

\begin{tabular}{|c|c|c|}
\hline Social Field & Economic Field & Environmental Field \\
\hline $\begin{array}{ll}\text { - } & \text { Sociocultural influence on } \\
\text { local population } \\
\text { - } & \text { Public safety } \\
\text { - } & \text { Cultural } \\
\text { heritage conservation } \\
\text { - } \quad \text { Changes in } \\
\text { population structure } \\
\text { - } \quad \text { Social carrying capacity of } \\
\text { the site } \\
\text { - Changes in } \\
\text { population well-being } \\
\text { Urban } \\
\text { landscape improvements }\end{array}$ & $\begin{array}{ll}- & \text { Tourism benefits for } \\
\text { - } & \text { host communities } \\
& \text { Tourism incomes } \\
\text { - } & \text { for destinations } \\
- & \text { Tourist satisfaction } \\
- & \text { Development control } \\
& \text { Tourist facilities providing } \\
\text { - } & \text { variety of experiences } \\
- & \text { Seasonality } \\
- & \text { Employment } \\
- & \text { Tourism-related transport } \\
- & \text { Destination competitiveness } \\
- & \text { Tourist routes } \\
- & \text { Cultural investments } \\
\text { Agglomeration and spatial } \\
\text { distribution of sites }\end{array}$ & $\begin{array}{ll}- & \text { Protection of natural asset } \\
- & \text { Energy management } \\
- & \text { Water availability } \\
- & \text { Water management } \\
- & \text { Wastewater treatment } \\
- & \text { Solid urban } \\
& \text { waste management } \\
- & \text { Atmospheric pollution } \\
- & \text { Visual impact of facilities } \\
- & \text { and infrastructures } \\
- & \text { Intensity of use } \\
\text { Environmental management }\end{array}$ \\
\hline
\end{tabular}

In this method of analysis, the built environment is often neglected despite the many features that characterize it, which are affected by the influence of tourism-related phenomena.

Surely, in the wide analysis of Lozano-Oyola et al. [73], it is relevant to underline that the built environment is considered in the conservation of cultural heritage and improvement of the urban landscape as a baseline social aspect. In detail, cultural heritage focuses on the number of protected cultural heritage sites, and uses voluntary contributions and heritage use intensity as indicators. The urban landscape aspect focuses, among the others, on the indicators of building renovation costs and the improvement of the urban environment in relation to available funds.

We think that it is fundamental to extend the indicators on the built environment, especially in cultural tourism, in which it is one of the driving forces of tourist flows. It is also necessary to extend the perspective of the analysis through considering the built environment, the urban development dynamics, and their relationship with the tourism phenomena as the central focus of the issue.

\subsection{From Heritage Impact Assessment to a Systematic Explicitation of Tourism Flow Impacts on the Built Environment}

The above considerations give the opportunity to propose a change of perspective in the evaluation systems, since they seem to leave out some fundamental aspects that require further integration.

In many ways, the problem of cultural tourism in the field of sustainability involves the resources from which it originates. Architectural and historical heritage become the motivation of tourists that want to appreciate not only the tangible values, but also the intangible ones.

It is necessary to start from considerations at the architectural level as a basis for extending critical thinking to cities as well.

If we think about the role that architectural heritage has as the driving force and cornerstone of an entire sector, we also understand that a unique vision cannot ignore the link between sustainability, tourism, and building heritage. From this perspective, the built environment assumes a completely 
different weight with respect to the current evaluation systems. The analysis has to link the valuable architectures to the tourist flows that are the first positive and negative catalysts, and thus have the most influence on conservation policies.

In this way, it is possible to start from the consideration of the physical impacts that a cultural asset undergoes when it becomes a local attraction and a strong catalyst for tourism dynamics.

Tourist flows and cultural heritage are related to each other through dichotomous and contrasting aspects that cannot always be quantified optimally. The need to understand these dynamics puts us in front of the problem of identifying the impacts that derive from it, as well as direct and indirect threats. It is extremely useful if we think of cultural heritage as the key element for the sustainable development of human societies $[79,80]$.

Among the existing methodologies, the Heritage Impact Assessment (HIA) promoted by Seyedashrafi et al. [80] and ICOMOS [81] for UNESCO sites certainly helps to define the starting points for built heritage and, more precisely, the Outstanding Universal Value (OUV) sites. The document by ICOMOS [81] provides a series of guidelines to carry out the HIA in a rigorous and complete way.

This methodology derives from the environmental impact assessment (EIA), and consists of a process of identifying the future consequences of a current or proposed action.

In particular, the Cultural Heritage Impact Assessment (CHIA) is defined as "the process of identification, prediction, evaluation, and communication of the probable effects of a policy or development action on the cultural life, institutions, and resources of communities, [and] then integrating the findings and conclusions into the planning and decision-making process, looking at the mitigation of adverse impacts and enhancing positive outcomes" [80,82].

According to ICOMOS [81], in order to minimize adverse impacts, every effort should be made to balance the public benefits and avoid damage to the site. It is also important to always evaluate who benefits from the proposed change, and for what reasons.

Impacts are classified according to beneficial and adverse effects, with five categories of values that are analyzed on the basis of five levels of impact severity.

Impact is defined as the difference between what would happen with an action and what would happen without it, and can obviously be both positive and negative [70], or both direct and indirect [81].

From the methodology described above, it is interesting to derive the impacts that the tourist flows have on a cultural asset or site and systematize them in a vision that takes the elements of sustainability into account. In fact, it is interesting to explain the relationship between tourist flows and architectural heritage in order to understand how to deal with the problem of the excessive exploitation of the site.

There are different types of impacts deriving from physical phenomena or the use of buildings that are linked to the excessive exploitation of mass tourism.

We find it appropriate to distinguish the effects of tourism on single historical buildings from the impacts that are generated on the overall urban context. According to Drdácký and Drdácký [83], six types of impacts and risks, originating from massive tourist flows, can be considered:

1. Environmental issues;

2. Damage and mechanical deterioration of historical structures;

3. Intentional damaging (vandalism and terrorist actions): accidental abrasions on surfaces, increase in vibrations, daily load or overload on bearing structures; scores, inscriptions, and removal of monument parts, etc.;

4. Ignorance and negligence of tourists;

5. Buildings' transformations and modernization;

6. Conflicts of use.

This consideration led to the need for a careful thinking and an explication of the most widespread impacts on historical sites or cities. These impacts are often analyzed via traditional methodologies that have been designed for assessing built heritage, but are also related to specific contexts and 
local sites. In this attempt, it is essential to relate the type of destination to the mass tourist flows in order to understand the types of impacts that happen: in the context of urban dynamics and architectural dimension, we have to think of what kind of tourism develops in the city. This is why two essential types of urban tourism come into play. The first one consists of tourist movements toward a well-defined area and a specific site of inestimable historical, architectural and artistic value. In the second type of tourism, parts of the city, such as the historical centers, or the entire city itself, become the object of attraction and the catalyst of the flows.

Starting from these two dimensions, we can contextualize and list a series of impacts of different types, and then derive from them various types of threats.

Among them, there are environmental impacts (e.g., on structures and physical properties, through the conservation state, microclimate, thermo-hygrometric comfort, and energy consumption derived from plant systems), visual impacts (e.g., visual integrity), historical documental (e.g., on the authenticity and integrity of the site), and social impacts (e.g., on the attractiveness, through use by tourists and residents, and migratory movements of the local population).

Therefore, they can be merely induced by the presence of people at the sites, generating physical and microclimatic phenomena that could change or damage their integrity (Table 2), or they can be derived from the methods of fruition and use of the buildings due to crowding or a use that is not in harmony with its original value (Table 3).

Table 2. Identification of impacts on building structure and microclimate induced by intense tourism flows.

\begin{tabular}{|c|c|c|c|}
\hline \multirow[t]{2}{*}{ Architectural Attributes } & \multicolumn{3}{|c|}{ Threats Derived by Change of Physical Parameters } \\
\hline & $\begin{array}{l}\text { Rising internal/external } \\
\text { temperature }\end{array}$ & Increasing relative humidity & $\begin{array}{l}\text { Increase in } \mathrm{CO}_{2} \text {, particulates, and } \\
\text { dust lifting }\end{array}$ \\
\hline $\begin{array}{l}\text { Material and } \\
\text { structural elements }\end{array}$ & $\begin{array}{ll}- & \text { Deterioration of mortars } \\
\text { - } & \text { Structural damage }\end{array}$ & $\begin{array}{ll}- & \text { Masonry structural damage } \\
- & \text { Mortars deterioration } \\
- & \text { Damage on structural integrity }\end{array}$ & \\
\hline Decorative elements & $\begin{array}{l}\text { Cracks or deterioration } \\
\text { due to thermal stress to } \\
\text { tiles, plaster coatings, } \\
\text { decorative finishes, and } \\
\text { so on. }\end{array}$ & $\begin{array}{l}\text { Deterioration or damage to tiles, } \\
\text { plaster coatings, and } \\
\text { decorative finishes. }\end{array}$ & $\begin{array}{l}\text { - Deterioration or damage to tiles, } \\
\text { plaster coatings, and decorative } \\
\text { finishes through the creation of } \\
\text { external dirty layers. }\end{array}$ \\
\hline Shape and Design & $\begin{array}{l}\text { Intervention on the } \\
\text { building's envelope } \\
\text { (where it is possible) and } \\
\text { plant systems. }\end{array}$ & 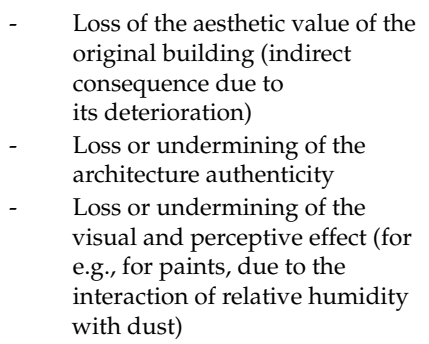 & $\begin{array}{l}\text { - Loss of the aesthetic value of the } \\
\text { original building } \\
\text { - } \quad \begin{array}{l}\text { Loss or undermining of the } \\
\text { architecture authenticity }\end{array} \\
\text { - Loss or undermining of visual } \\
\text { and perceptive effects }\end{array}$ \\
\hline Indoor thermal comfort & $\begin{array}{ll}\text { - } & \text { Indoor } \\
\text { thermal discomfort } \\
\text { - } \quad \text { Increase of cooling } \\
\text { energy need for summer. }\end{array}$ & $\begin{array}{ll}\text { - } & \text { Indoor thermal discomfort } \\
\text { - } & \text { Need for dehumidification }\end{array}$ & $\begin{array}{l}\text { Increase of the unsustainability } \\
\text { of the asset from the } \\
\text { environmental point of view }\end{array}$ \\
\hline
\end{tabular}

In the latter cases (Table 3), it is no longer a question of the impacts induced in an almost passive manner, but rather of consequences derived from the active attitudes of tourists. For this reason, they are potential, rather than certain impacts. They determine the different levels of perception that are induced in both tourists and residents (such as the perception of the site value, its sense of identity, the aim of conservation of the site as an intangible value entity, and the link between the local population and the architecture itself).

This kind of impact also depends on the organizational choices made by the associations or organizations that manage these sites (such as, for example, the use of every part of the building, 
the closure of some areas of the site that lead to overloading the open areas, the lack of different values except for the tourist one, functional mix, and so on).

As a result, with the proposed tables, we tried to provide a sort of synoptic framework and list the impacts that can concern a historical building, deriving from intense tourism flows that are either concentrated or widespread throughout the city.

Although the presented framework is far from being exhaustive, it does propose a focus on aspects that are often neglected at the theoretical level, and which lead to environmental and social problems that are important, but have not been well explained in the literature.

The tables show how the impacts on the site can be heavy. At an architectural level, the architectural asset is affected by excessive use and exploitation, which leads to real physical damage, deterioration, and degradation, in addition to an increase in energy needs as a result of the air conditioning systems. At the urban level, the dynamics of mass tourism upset the perceptual levels not only of the tourist but also of the inhabitants, who no longer feel that the tourist site is a marker of the identity of the place where they live. In this way, a depersonalization of the sites occurs. If the residents do not feel ownership over the sites, the architectural built heritage is left in the hands of mere bearers of economic interests, who have little interest in preserving the intrinsic values of the places, which is linked to traditions, and aspire very much to simple "appearances "of integrity and authenticity.

Table 3. Identification of impacts deriving from use of buildings linked to intense tourism flows.

\begin{tabular}{|c|c|c|}
\hline \multicolumn{3}{|c|}{ Threats Derived by Use of Historical Buildings and Sites ... } \\
\hline & Overcrowding in the site & $\begin{array}{l}\text { Destination use not compatible with the } \\
\text { original asset value and function (e.g., closing } \\
\text { of certain parts to the public) }\end{array}$ \\
\hline $\begin{array}{l}\text { Architectural Attributes and } \\
\text { Settings }\end{array}$ & $\ldots$ in Concentrated Tourist Flows & \\
\hline $\begin{array}{l}\text { Material and structural } \\
\text { elements }\end{array}$ & - $\quad$ Eventual damage due to operating loads & $\begin{array}{l}\text { Eventual damage due to possible } \\
\text { additional loads for which the structure is } \\
\text { not able to compensate }\end{array}$ \\
\hline Decorative elements & $\begin{array}{l}\text { - Eventual damage due to carelessness or } \\
\text { the distraction of tourists }\end{array}$ & \\
\hline Shape and design & $\begin{array}{l}\text { - } \quad \text { Difficulty in the fruition of the site } \\
\text { - } \quad \text { Loss of visual and aesthetic value } \\
\text { Loss or undermining of the attractiveness } \\
\text { of the asset }\end{array}$ & $\begin{array}{l}\text { Different functional distribution of the } \\
\text { spaces with the need to insert new } \\
\text { services (e.g., service rooms, elevators, } \\
\text { refreshment points, etc.) }\end{array}$ \\
\hline $\begin{array}{l}\text { Indoor thermal and visual } \\
\text { comfort }\end{array}$ & $\begin{array}{l}\text { - Undermining of visual perception and } \\
\text { visual comfort of the site } \\
\text { - } \quad \text { Reduction of hygrothermal comfort }\end{array}$ & $\begin{array}{l}\text { - Inadequacy of indoor climate conditions } \\
\text { (e.g., museum destination for an } \\
\text { inadequately air conditioned building) } \\
\text { - } \quad \text { Installation of possibly invasive plant } \\
\text { systems (even in respect of } \\
\text { conservation politics) }\end{array}$ \\
\hline Original function & $\begin{array}{l}\text { Departure of the local population from } \\
\text { the use of the buildings }\end{array}$ & $\begin{array}{l}\text { - Potential loss of the original function (e.g., } \\
\text { a loss of ritual function in churches) } \\
\text { Consequent departure of the local } \\
\text { population from frequenting the building }\end{array}$ \\
\hline Surrounding context & $\begin{array}{l}\text { - } \quad \text { Change of townscape } \\
\text { - } \quad \text { Undermining of visual integrity }\end{array}$ & 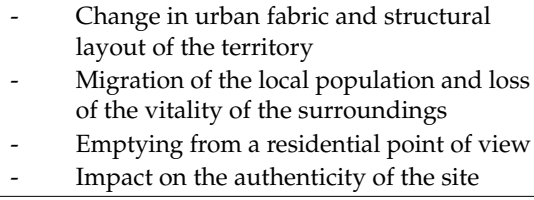 \\
\hline $\begin{array}{l}\text { Urban and Built } \\
\text { Environment Attributes }\end{array}$ & ... in Widespread Tourist Flows & \\
\hline $\begin{array}{l}\text { Material elements and urban } \\
\text { structural invariants }\end{array}$ & $\begin{array}{l}\text { Eventual damage due to the carelessness } \\
\text { or distraction of tourists }\end{array}$ & $\begin{array}{l}\text { - Possible damage and/or modifications, of } \\
\text { structural invariants (e.g., from the point } \\
\text { of view of mobility and transport) } \\
\text { - Change in the conformation of the } \\
\text { structural urban fabric }\end{array}$ \\
\hline
\end{tabular}


Table 3. Cont.

\begin{tabular}{|c|c|c|}
\hline \multicolumn{3}{|c|}{ Threats Derived by Use of Historical Buildings and Sites... } \\
\hline Decorative elements & $\begin{array}{l}\text { Eventual damage due to the carelessness } \\
\text { or distraction of tourists }\end{array}$ & \\
\hline Urban shape and design & $\begin{array}{l}\text { - } \quad \text { Difficulty in the fruition of the site } \\
\text { - } \quad \text { Loss of visual and aesthetic urban value } \\
\text { Loss or undermining of the attractiveness } \\
\text { of the asset }\end{array}$ & 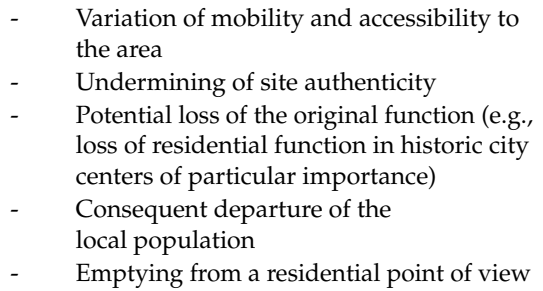 \\
\hline $\begin{array}{l}\text { Urban microclimate and } \\
\text { outdoor visual comfort }\end{array}$ & $\begin{array}{l}\text { - Undermining of visual perception of } \\
\text { the site } \\
\text { - } \quad \text { Increase in air pollution }\end{array}$ & \\
\hline Original function & $\begin{array}{l}\text { Departure of the local population from } \\
\text { the fruition of the site }\end{array}$ & $\begin{array}{l}\text { Loss of the historical and } \\
\text { original function }\end{array}$ \\
\hline Surrounding context & $\begin{array}{ll}\text { - } & \text { Change of townscape } \\
-\quad & \text { Undermining of visual integrity }\end{array}$ & $\begin{array}{l}\text { - } \quad \begin{array}{l}\text { Loss of function mix and exclusively } \\
\text { tourist vocation of the whole city }\end{array} \\
\text { Excessive exploitation from the } \\
\text { commercial / receptive point of view of } \\
\text { the surrounding area } \\
\text { - } \quad \text { Townscape modification } \\
\text { - } \quad \begin{array}{l}\text { Migration of the local population and loss } \\
\text { of the vitality of the surroundings }\end{array}\end{array}$ \\
\hline
\end{tabular}

\subsection{A Double-Focused Integration of the "Downstream" Perspective: Buildings' Intrinsic Indicators}

In the previous paragraphs, we tried to represent a framework of key issues of sustainable urban tourism as it emerges from the available literature, i.e., as the result of the confluence of several concepts: urban sustainability, tourism, and sustainable development. Tackling the task of defining sustainable urban tourism by analyzing its conceptual components represents a complex problem; such complexity emerges, especially at the level of measurement, since different sets of indicators, pertaining to each specific field, end up mingling in the effort of describing this area of concern. Thus, an articulated, and eventually bewildering, body of indicators comes into play.

Our reflections are based on the identification of two necessities: on one hand, changing the way of dealing with the problem through a shift in perspective, and on the other hand, narrowing the observation scale for the definition of possible indicators.

\subsubsection{A Shift in Perspective: From Passive to Active Cities}

In relation to the first point, we observe that the panorama of indicators and analyses related to sustainable tourism in urban contexts encompasses issues that mainly relate to the source (the tourism activity), i.e., indicators pertain essentially to the more or less sustainable way of traveling to, staying in, and visiting places. Actually, it would be necessary to first move the field of analyses to the 'city', which is meant not only as a passive recipient of tourism practices and patterns and the related impacts, but also as an element that has an active part in the play. Since numerous studies $[35,84,85]$ have clearly highlighted the need to bring tourism within the wider sphere of urban planning, it makes sense to consider the city as 'jointly responsible' for its effects, in a way. Indeed, this already occurs in research works, but up to now, previous studies have only assessed the consequences and impacts downstream of the tourism activity-which has been more or less integrated with the other urban functions-and focused on essential mitigation measures. In our opinion, it appears more appropriate to identify within the inherent characters of the urban context, upstream of the occurrence of any actual flow, the premises for a really sustainable urban tourism. Following on from this new focus, the expression "sustainable urban tourism" ought to be replaced with the phrase "tourism-related sustainability of the city". Such a redefinition is not about mere wordplay; this, we believe, generates a beneficial time 
advance in the planning of activities and measures to adopt, since it enables relying on a description of the city's capability to be more or less effectively both the object and subject of sustainable urban consumption, regardless of any actual flow event.

In our opinion, a first positive advancement could be achieved by extending to the built environment an evolution in the notion of carrying capacity that was conceived and is currently and applied at the wide-area or regional scale [86]. Such evolution consists in turning the limiting concept of carrying capacity, which was originally meant as a critical threshold for the transformation processes, into the positive term of "ability" through a substantial acceptance of tourism-induced transformations. The transition from "carrying capacity" to "carrying capability" leads to conceiving of this requisite as a tolerability range for urban transformations, rather than as a sharp limit that must not be exceeded. Thus, the widespread negative connotation of tourism phenomena comes to be deeply innovated by accepting the changes associated with such activities and defining their compatibility domain. Such conceptual evolution is based on LAC ("limits of acceptable change") methodologies and adaptive management principles, and these features reconnect quite naturally to the concept of the adaptivity of the built environment, and by extension, of cities.

Part of the available literature $[39,87]$ discusses the different abilities of cities to absorb impacts, re-adapting themselves according to their respective technical, economic, and skill resources in an active way. We find it consistent, then, to translate this passage into a re-definition of some important indicators-such as, indeed, the carrying capacity—and their application to specific components of the urban context.

Moreover, such an approach is consistent with the latest shift in attitude among institutions, which is toward a renewed consideration of the positive cultural, social, and economic repercussions of tourist activities [88] as a means to pursue sustainability in the overall urban development, after the flourishing of studies addressing negative externalities and the critical positions shared by a large part of the academic world.

From this new perspective, the definition of mitigation actions, which are expected as part of the main content of planning instruments, can move downstream of assessment, monitoring, and comparison with the desired objectives, thus allowing a reduction in the size of the measures that ought to be adopted.

\subsubsection{The Building Scale for the Definition of Indicators}

As for the second point, it must be observed that in the general 'scope' of sustainable urban tourism, some conditions are to be found that are widely acknowledged and shared in the literature, regardless of approaches. Firstly, the fastest growing component in urban tourism is cultural tourism, i.e., tourism that is linked to heritage and material resources in particular; secondly, positive effects on local economies are mostly exerted through the promotion of tangible heritage; thirdly, the built fabric is the main component of the urban environment and morphology, hosting almost the totality of time and activities of tourists and inhabitants (apart from transport, which is outside the scope of this study); lastly, the built component of cities is the main source of environmental impacts (i.e., materials, water, and energy consumption, and waste production for construction, use, and demolishing). The importance of the built environment, and of buildings in particular, is then central in the consideration of the sustainability of tourism and urban development in general.

Evidence in support of this is to be found in the broad attention paid, in the literature as well as in practice, to adaptive reuse as one of main strategies to address-through the physical and functional revitalization of ancient disused or obsolete buildings-urban problems arising from intense visitor flows and the displacement of residents from central locations [89,90]. Among the different definitions in the literature, which range from the most commonplace ("recycling of buildings") to more articulated definitions that differ in terms of the contents and objects of actions [91-93], in our opinion one can be considered the noblest: "developing the potential of additional uses for functionally obsolete buildings" [94]. This means bringing to light a hidden potential of "additional" (not 'new') 
uses that are already inherent in the buildings, and therefore not inventing something extraneous to the buildings. In the first place, this definition demands that operators study the building in question in order to understand its potential. However, even with that, the best imaginable intervention in technological. Functional and aesthetic terms will not deliver the expected effects in relation to rebalancing the pressures among the different parts of the city if the public does not use the building in everyday life. The latter could occur if residents have not realized the building's value, or because developers failed in conceiving reuse from a profound knowledge of the building. In other words, the building or complex must be, at the same time, re-adapted and re-adopted.

The magic that must be fulfilled is residents and visitors discovering how a building that has had a specific (identity-making, in the case of buildings with historic and architectural heritage) meaning in the past perfectly suits their current needs, and how these two uses coexist naturally and harmoniously, without conflict. It is difficult, but not very difficult; it is enough to move toward the building with the conviction that it already has those new uses in itself, by nature. Thus, coming to know it, acting on it respectfully, and ensuring that all of this is adequately conveyed to residents and visitors, is all that is needed to awake latent potentials and capabilities and bring them into the present life.

This allows us to identify a further important element that should be included among building-scale and neighborhood-scale indicators for urban and tourism development purposes: knowledge. Knowledge (for developers, tourists, and inhabitants) can be a great indicator of the sustainability and resilience of the urban fabric that is called upon to withstand tourism impacts. It is essential that this knowledge of assets be available and accessible, and more or less formalized. If it has gone missing or cannot be found, interventions are likely not to be effective in pursuing the hoped positive effects. This leads to consider other issues: information accessibility (undermined by the traditional "closedness" of information of heritage [95]), to which Information and Communication Technologies (ICTs) for the collection and organization of data can anyway offer adequate support [8], and public participation in decision-making, which, on the contrary, is not as easy to solve and must rely on the sensitivity of local governments in charge.

Again, for the purposes of adaptive reuse as a preferential strategy for the design of solutions to urban tourism impacts, other indicators can be identified. Form, for example, and the organization of internal space are further indicators that allow the evaluation of buildings and complexes with reference to their greater or lesser suitability to be objects of effective actions of adaptive reuse, and their greater or lesser ability to contribute to the overall sustainability of the urban environment.

Finally, the technological and plant system endowment of assets must be considered with reference to their ability to support the necessary adaptation to current performance standards, as well as features that are specifically related to the reversibility of specific building parts.

We believe that these indicators can and should be usefully integrated with the indicators that are more widely used to assess the sustainability levels of the built environment. As a result, a set of indicators could be defined that also include issues related to the management and redirection of tourist and other impacts. In fact, tourism is not the only source of overcrowding in cities; more and more, the built environment will have to be analyzed and assessed for its ability to facilitate the harmonious reorganization of urban functions (housing, work, leisure, services) among the different urban zones, considering also the needs generated by the migrant flows, which add burden to the context.

Ultimately, even if a part of the literature stresses that indicators at the scale of single buildings must be case-specific, thus supporting little comparability, some 'core', cross-cutting indicators do exist that are common to all contexts. Once adaptive reuse is accepted as universally beneficial, those indicators are useful, and should always be used, to assess the ability of a building or group of buildings to be sustainable or resilient toward impacts coming from urban tourism and similar phenomena, and substantially express their suitability for reuse. To sum up, some of these indicators, which are applicable to all building types, include: technological adaptability to standards, form and internal space organization (interior layout)—which are often the last to evaluate in terms of flexibility (i.e., suitability for multiple possible uses)—and closeness to a predetermined functional 
goal. In this respect, the insights given by many authors that have supported the relationship between form or typology and possible uses with theoretical and applied studies, which in particular include the typological technical or programmatic approaches described by Plevoetz and Van Cleempoel [93], as well as Brooker and Stone [96]. However, before these, in the case of buildings with historical and architectural value, available knowledge that has been variously codified is of primary importance.

The need to relate the indicators of tourism sustainability for cities to the building scale also rests on the possibility of easily including buildings in the general assessment of value, and in particular in real estate evaluations, so as to really and concretely renovate current dynamics. In this way, the sustainability goals of urban transformations would be more efficient in reorienting property-related developments, which are often finance-driven. Furthermore, the ability of medium-term research studies to define a building-scale and a neighborhood-scale 'carrying capability' would allow better monitoring and counterbalancing effects among parts of the urban contexts, as well as managing flows and strategies at the municipal level.

In general, indicators at these scales can suitably support analyses equipped through GIS technologies, which have recently been extending the range of tourism-related applications from the field of marketing to the study of connections among tourism, planning, and sustainable development issues [97-101]. Such technologies have provided tools for addressing open questions in the research, and complementing current regional and wide-area studies with new analyses at the sub-urban scale.

The purpose of the present article is not to deliver a defined and detailed set of indicators, but rather to throw light and draw attention on the need to focus research at the scale of the built environment and single buildings. Furthermore, our claim is not to be exhaustive; in this work, we leave well-known and obvious indicators out of consideration (material, energy and water consumption, waste generation) that have been commonly associated with construction, whether of monuments or ordinary stock, and widely adopted within current assessment schemes. Instead, we focused our aim on reflecting and stimulating a deepening and detailed definition of new indicators.

As to the specific issue of consumption, some observation can nonetheless be made. In the overall literature on cultural heritage and the built environment in general, a prevailing tendency can be observed to relate the term "consumption" to resource use by tourists, and the term "fruition" to local residents. Such a distinction can only partially be justified by the greater rapidity and intensity of resource use by visitors due to the shortness of stays, the intention of "intensely" living the tourist experience, and the general less cautious and frugal attitude on vacation. As a matter of fact, it must be considered that, on one hand, residents and visitors are not so sharply distinguishable since they share the same resources, and on the other hand, residents' consumption patterns cannot be taken for granted. Such a widespread tendency leads to considering tourism as "the" unbalancing factor within a situation that is mostly balanced and sustainable in itself, which itself as a direct consequence leads to determining an approach that is mainly focused on the provision of limitations to tourists, and thus in a way "exonerating" local inhabitants from reviewing their own everyday consumption patterns. This is in line with the tendency to approach tourism impacts by integrating downstream mitigation measures that result in "punitive" measures for visitors, with intangible repercussions on the visit experience and tangible evidence in terms of limited obtainable savings. Just for the widespread call to include tourism in the general domain of urban planning, and just because sustainable development means the harmonious integration of the two functions-tourist and residential, in wide terms-it is correct to aim at a common cultural pattern of respectful fruition. Since almost all cities are gradually learning to promote their own unique identities and heritages, turning into tourist destinations and tourism is only one possible flow carrier. Such flows can no more be considered as more or less frequent "events" to be remedied when occurred, but should be rather received and acknowledged as part of the living fabric of the city and everyday life. In terms of indicators, it undoubtedly makes sense to create conditions to quantify and monitor consumptions separating the two data sources and enhance the modeling of the different use patterns, but with the aim of defining modalities of 
spatial (among different parts of the city) and temporal (on a daily to seasonal basis) conciliation and compatible coexistence.

\subsection{Evidences of the Built Environment's Role from Major Dilemmas of Tourism}

Summing up, sustainable tourism is currently a complex issue, because it has different implications-social, environmental, and economic - if we look at the problem through the lens of the triple bottom line. In fact, Ritchie and Crouch [102] also theorize the existence of a fourth "pillar of sustainability" represented by institutional sustainability, assuming that in democratic countries, the institutions and their approaches fully adhere to the social, environmental, and economic objectives, while in the totalitarian regimes, the aspirations and interests of the community struggle against those of the decision-making class. Actually, in many contexts, such a distinction is not so easily and directly made; mainly, institutional sustainability cannot always be correctly positioned, conceptually, at the same level as the other three pillars for two reasons. Firstly, the political objectives, far from being homogeneous with respect to the other three groups, represent rather a lens that overlaps them. This lens then dilutes or modifies them, since politics requires mediating the original goals with the self-sustainability and survival objectives of the institutions themselves in a pluralistic scenario. In addition, the objectives of environmental, economic, and social sustainability are undeniable, invariable, and easily identifiable, because they are transversal and universal: all people in the world desire, in the same way, the conservation of resources, absence of pollution, acceptable income levels, and a peaceful coexistence. The objectives of institutional sustainability are not as univocal: even in democratic regimes, minorities remain excluded or disadvantaged by the political sustainability judgments and decisions of the majority. This is because there is the intermediate filter of interpretation, from the part of the political class, of peoples' interests and desires, and because the individual element to some extent comes into play beside the universality of collective values, in spite of, or due to, the mechanisms of delegation.

The need to bring urban tourism into the wider framework of city planning and urban development control has been acknowledged in the literature, which entrusts it nevertheless to the management of governments. It is necessary to recognize this limitation within the political level, and then carefully grasp the role of local institutions, which-paradoxically matching the pursuit of universal objectives - can safeguard the local communities' needs and interests through the knowledge of context-specific problems, and thus help reduce the complexity of this issue. The ultimate objective of sustainability, thanks to its global/local dimension ("think globally, act locally") is in our vision the privileged ground on which deontology (universal principles) and teleology (the local effects of decisions) can positively meld. Yet, in the tourist sector, the general trend towards an explicit anti-tourism, of which the demonstrations of Venice, Barcelona, Palma de Mallorca, and Amsterdam in 2017 are just a few examples, is interpreted by Misrahi [103] as the proof of the failure of such destinations being simultaneously sustainable and competitive. Ritchie and Crouch [102] also underline the difficulty of reaching a balance between those two concepts. Thus, due to this difficulty, it is necessary to mobilize the potential capital of cities and their built environment before the collision between sustainability and competitiveness occurs at the level of events, and their tangible effects eventuate.

Moreover, according to Ritchie and Crouch [102], the concept of the "long term" is at the core of a "sustainable competitiveness". In our vision, buildings, due to their particularly extended service life, shall necessarily have a role and a voice in the scene, shaping tools and strategies. Omitting this consideration in the analyses and focusing on downstream mitigation actions, which tend to be time-limited and emergency-driven, would represent a significant undervaluation mistake. The restrictions applied, among others, to the number of admitted visitors or cruise ships, to walkable routes or physically accessible resources in Santorini Island, Venice, Machu Picchu, or the Cinque Terre, are extreme measures that introduce tangible signs of unfriendliness to visitors. As such, they intensify 
the tension between visitors and residents, sealing their sharp separation, and impress the image of the negative effects of tourism in the perception of locals.

Two important remarks of McKercher in Ritchie and Crouch [102] regarding the "fundamental truths on tourism", are to be specifically considered. Firstly, it is an industry ruled by private sector logics, and by the main objective of profit maximization. Actually, the ultimate anomaly of tourism, i.e., that most of the direct benefits associated with it favor only limited groups of people, while its negative fallout affects the whole community of a destination, and most visibly the built environment, is becoming more and more apparent. Theoretical statements on strategies for the spatial re-distribution of tourist flows and their general benefit for both tourists and residents, although useful to an extent, tangle with material evidences of an unbalance between the involved groups. On one side, there is the seasonal character of tourism revenues, which is hardly perceivable among the whole community; on the other side, the effects in terms of house prices that increase without substantial seasonal fluctuations affect all citizens, particularly the weaker groups.

The second basic truth identified by McKercher is that tourism is a many-sided industry that is almost impossible to control [102]. It is exactly because of this impossibility to govern tourism, and then to contain its effects through mitigation or limitation measures, that we find it important to shift considerations and actions upstream of the production of impacts through tourism activities.

In such a deeply unbalanced development, where statements on the universal nature of heritage property rights coexist with a lack of a universal right to tourism, discrimination regarding access to specific nations, and the 'global mobility divide', the number of "potential" tourists is substantially high. Against communities-including the most disadvantaged ones- that are being asked to participate in bearing the tourist burden, it is the global north, the developed part of the planet, that mostly enjoys the right to tourism, which in the cultural sector is particularly marked by high levels of individual expenditures. Such issues are acquiring a growing visibility, and increasing visitor flows can be reasonably expected as these issues are addressed and solved. Consequently, the possibility of relying on restrictions and mitigation measures appears increasingly insufficient; the ability to correctly read and mobilize the potential contribution of the built environment and make the most of its reception capability is, now more than ever, strategic.

\section{Conclusions}

To summarize, sustainable tourism is currently a complex issue because it involves social, economic, and environmental implications. In the existing approaches to the problem and assessment methods, it is clear that there is a need to focus on the built environment as a main component of the urban context. In fact, the interaction between buildings/cultural heritage, and the tourist flow is one of the key factors in exploring impacts not only on building features, but also on the social aspects and perceptions that derive from mass tourism.

Although our analysis is far from exhaustive, the paper wants to suggest possible additional building-scale influence factors to consider in current downstream evaluation in order to identify mitigation practices.

In the continuation of this research, an immediate subsequent step can be seen in the deepening of the suggested indicators, with reference to what quantitative and qualitative areas can be identified within them, thus leading to better detailing possible sub-level indicators. Consequently, metrics for their evaluation could be considered.

Another important refinement of the study, at a later stage, should be the integration of considerations on the 'perceived' impacts in the framework. This could be best accomplished through case studies and on-site investigations aimed at building a weighing system that is able to express the greater or lesser importance that communities assign to the different impact components.

We consider it necessary also to aim at the integration of building-related indicators with those that holistically consider the destination as a whole, so as to support the definition of 
context-tailored measures within city planning that are able to consider urban, suburban, neighborhood, and building dimensions.

Moreover, the indicators proposed could effectively integrate with other more specifically tourism-related indicators, if a similar approach were to be applied by referring conventional indexes such as tourist pressure (i.e., tourists-to-residents ratio) and the beds-to-residents ratio to single buildings or building blocks. This would stimulate research focusing on mixed-use buildings, which represent an interesting and rather unexplored context for promoting the integration of communities.

Broadening the view, another consideration can be added to the proposed approach. Given the exploratory nature of the work, some simplifications have been introduced in the rationale: firstly, the 'public', i.e., the residents' and visitors' communities, have been referred to as compact groups; secondly, the value of a building for its local community or its appreciation level has been considered univocally determinable. That means overlooking variability in the management of the described processes.

For example, in reuse interventions, the effective grade of the building's 'presence' in the everyday lives of residents is to be considered. If the asset is disused, residents are more likely to accept seeing it be visited by tourists, while if it is (or has long been) a living part of urban use patterns, it could not be as easy to predict whether the pride of sharing it will prevail over the fear of damaging it or simply the sense of 'intrusion'.

Although this kind of generalization is far from being infrequent in research on this topic, we think that in order to leave globalization and homogenization out of the picture, preference-related issues should be explored. Thus, a possible further deepening of these aspects could greatly contribute to the appreciation and diffusion of the approach by introducing subjectivity considerations. Although these considerations are out of our specific scope, such integrations would be of great interest.

Author Contributions: The authors contributed equally to the ideation and development of the study: conceptualization, investigation, methodology and writing of original draft. A.L. wrote introduction, main proposals and discussion, conclusions (Sections 1, 2, 4.3, 4.4 and 5). S.D.T. wrote literature review, approach analysis, main proposals and discussion (Sections 2, 2.1, 3, 4.1 and 4.2).

Acknowledgments: The authors appreciated the encouraging support and credit received by Antonio Occhiuzzi, Director of Construction Technologies Institute-National Research Council of Italy, and Nicola Maiellaro, Local Responsible for the Construction Technologies Institute, branch of Bari.

Conflicts of Interest: The authors declare no conflict of interest.

\section{References}

1. Saarinen, J. Critical Sustainability: Setting the Limits to Growth and Responsibility in Tourism. Sustainability 2014, 6, 1-17. [CrossRef]

2. Hardy, A.; Beeton, R.S.; Pearson, L. Sustainable tourism: An overview of the concept and its position in relation to conceptualisations of tourism. J. Sustain. Tour. 2002, 10, 475-495. [CrossRef]

3. Jamal, T.; Camargo, B.A.; Wilson, E. Critical Omissions and New Directions for Sustainable Tourism: A Situated Macro-Micro Approach. Sustainability 2013, 5, 4594-4613. [CrossRef]

4. Moscardo, G.; Murphy, L. There is No Such Thing as Sustainable Tourism: Re-Conceptualizing Tourism as a Tool for Sustainability. Sustainability 2014, 6, 2538-2561. [CrossRef]

5. Rizio, D.; Gios, G. A sustainable Tourism Paradigm: Opportunities and Limits for Forest Landscape Planning. Sustainability 2014, 6, 2379-2391. [CrossRef]

6. Liu, Z. Sustainable Tourism Development: A Critique. J. Sustain. Tour. 2003, 11, 459-475. [CrossRef]

7. United Nations Environment Programme (UNEP); World Tourism Organization (UNWTO). Making Tourism More Sustainable-A Guide for Policy Makers. 2005, pp. 11-12. Available online: https: / /www.e-unwto. org/doi/book/10.18111/9789284408214 (accessed on 15 March 2018).

8. Lerario, A.; Varasano, A.; Di Turi, S.; Maiellaro, N. Smart Tirana. Sustainability 2017, 9, 2338. [CrossRef]

9. Liu, Z.H.; Jones, E. A systems perspective of sustainable tourism. In Proceedings of the International Conference on Urban and Regional Tourism, Potchefstroom, South Africa, 9-12 January 1996; pp. $209-221$. 
10. Moscardo, G. Exploring social representations of tourism planning: Issues for governance. J. Sustain. Tour. 2011, 19, 423-436. [CrossRef]

11. Getz, D. Models in tourism planning: Towards integration of theory and practice. Tour. Manag. 1986, 7 , 21-32. [CrossRef]

12. Marzuki, A.; Hay, I. Towards a public participation framework in tourism planning. Tour. Plan. Dev. 2013, 10, 494-512. [CrossRef]

13. Pforr, C. Concepts of Sustainable Development, Sustainable Tourism, and Ecotourism: Definitions, Principles, and Linkages. Scand. J. Hosp. Tour. 2001, 1, 68-71. [CrossRef]

14. Blangy, S.; Wood, M.E. Developing and implementing ecotourism guidelines for wildlands and neighboring communities. In Ecotourism: A Guide for Planners and Managers; Ecotourism Society: North Bennington, VT, USA, 1993; pp. 32-54, ISBN 0963633104.

15. Wall, G. Is ecotourism sustainable? Environ. Manag. 1997, 21, 483-491. [CrossRef]

16. Moscardo, G. Tourism and quality of life: Towards a more critical approach. Tour. Hosp. Res. 2009, 9, 159-170. [CrossRef]

17. Moscardo, G. Building social capital to enhance the Quality-of-life of destination residents. In Handbook of Tourism and Quality-of-Life Research; Uysal, M., Perdue, R., Sirgy, M.J., Eds.; Springer: New York, NY, USA, 2012; pp. 403-442.

18. Macbeth, J.; Carson, K.; Northcote, J. Social capital, tourism and regional development: SPCC as a basis for innovation and sustainability. Curr. Issues Tour. 2004, 7, 502-522. [CrossRef]

19. McGehee, N.; Lee, S.; O'Bannon, T.; Perdue, R. Tourism-related social capital and its relationships with other forms of capital: An Exploratory study. J. Travel Res. 2010, 49, 486-500. [CrossRef]

20. Sharpley, R. Responsible tourism: Whose responsibility? In The Routledge Handbook of Tourism and Environment; Holden, A., Fennell, D., Eds.; Taylor \& Francis: London, UK, 2013; pp. 382-391.

21. Jafari, J. Bridging out, nesting afield: Powering a new platform. J. Tour. Stud. 2005, 16, 1-5.

22. United Nations Department of Economic and Social Affairs. Population Division World Urbanization Prospects; The 2011 Revision; United Nations Department of Economic and Social Affairs/Population Division: New York, NY, USA, 2012; p. 318.

23. Schuetze, T.; Lee, J.; Lee, T. Sustainable Urban (re-)Development with Building Integrated Energy, Water and Waste Systems. Sustainability 2013, 5, 1114-1127. [CrossRef]

24. Kissinger, M.; Sussman, C.; Moore, J.; Rees, W.E. Accounting for the Ecological Footprint of Materials in Consumer Goods at the Urban Scale. Sustainability 2013, 5, 1960-1973. [CrossRef]

25. Di Turi, S.; Stefanizzi, P. Energy analysis and refurbishment proposals for public housing in the city of Bari, Italy. Energy Policy 2015, 79, 58-71. [CrossRef]

26. International Energy Agency. Energy Technology Perspectives 2012; IEA: Paris, France, 2012. Available online: www.iea.org (accessed on 7 March 2018).

27. Johansson, T.B.; Nakicenovic, N.; Patwardhan, A.; Gomez-Echeverri, L. (Eds.) Global Energy Assessment-Toward a Sustainable Future; UK and International Institute for Applied Systems Analysis: Cambridge, UK, 2012. Available online: www.iiasa.ac.at (accessed on 7 March 2018).

28. Fulton, L.; Lah, O.; Cuenot, F. Transport Pathways for Light Duty Vehicles: Towards a $2^{\circ}$ Scenario. Sustainability 2013, 5, 1863-1874. [CrossRef]

29. Alberti, M. Measuring urban sustainability. Environ. Impact Assess. Rev. 1996, 16, 381-424. [CrossRef]

30. Rees, W.E. Is sustainable city an oxymoron? Local Environ. 1997, 2, 303-310. [CrossRef]

31. Rees, W.E. Getting serious about urban sustainability: Eco-footprints and the vulnerability of 21st century cities. In Canadian Cities in Transition: New Directions in the Twenty-First Century, 4th ed.; Bunting, T., Filion, P., Walker, R., Eds.; Oxford University Press: Toronto, ON, Canada, 2010; pp. 70-86. Available online: http:/ / citeseerx.ist.psu.edu/viewdoc/download?doi=10.1.1.423.663\&rep=rep1\&type=pdf (accessed on 15 March 2018).

32. Newman, P. The Environmental Impacts of Cities. Environ. Urban. 2006, 18, 275-295. [CrossRef]

33. Grimm, B.N.; Faeth, H.S.; Golubiewski, E.N.; Redman, L.C.; Wu, J.; Bai, X.; Briggs, M.J. Global change and the ecology of cities. Science 2008, 319, 756-760. [CrossRef] [PubMed]

34. Ashworth, G.; Page, S.J. Urban tourism research: Recent progress and current paradoxes. Tour. Manag. 2011, 32, 1-15. [CrossRef] 
35. Fistola, R.; La Rocca, R.A. Driving Functions for Urban Sustainability: The Double-Edged Nature of Urban Tourism. Int. J. Sustain. Dev. Plan. 2017, 12, 425-434. [CrossRef]

36. Hernandez-Martin, R.; Rodriguez-Rodriguez, Y.; Gahr, D. Functional Zoning for Smart Destination Management. Eur. J. Tour. Res. 2017, 17, 43-58.

37. Wirth, L. Urbanism as a Way of Life. Am. J. Sociol. 1938, 44, 1-24. [CrossRef]

38. Smolčić Jurdana, D.; Sušilović, Z. Planing City Tourism Development: Principles and Issues. Tour. Hosp. Manag. 2006, 12, 135-144.

39. Caust, J.; Vecco, M. Is UNESCO World Heritage Recognition a Blessing or a Burden? Evidence from Developing Asian Countries. J. Cult. Herit. 2017, 27, 1-9. [CrossRef]

40. Law, C.M. Urban Tourism - The Visitor Economy and the Growth of Large Cities, 2nd ed.; Continuum: London, UK; New York, NY, USA, 2002; ISBN 0-8264-4928-X.

41. Burnett, P.; Cutler, H.; Thresher, R. The Impact of Tourism for a Small City: A CGE Approach. J. Reg. Anal. Policy 2007, 37, 233-242.

42. Hall, C.M. Tourism in Capital Cities. Tour. Int. Interdiscip. J. 2002, 50, 235-248.

43. Barrera-Fernandez, D.; Hernandez-Escampa, M.; Balbuena-Vazquez, A. Tourism Management in the Historic City. The Impact of Urban Planning Policies. Int. J. Sci. Manag. Tour. 2016, 2, 379-391.

44. Pavlic, I.; Portolan, A.; Butorac, M. Urban Tourism towards Sustainable Development. Int. J. Multidiscip. Bus. Sci. 2013, 1, 72-79.

45. Williams, P.W.; Ponsford, I.F. Confronting Tourism's Environmental Paradox: Transitioning for Sustainable Tourism. Futures 2009, 41, 396-404. [CrossRef]

46. Garcia-Hernandez, M.; de la Calle-Vaquero, M.; Yubero, C. Cultural Heritage and Urban Tourism: Historic City Centres under Pressure. Sustainability 2017, 9, 1346. [CrossRef]

47. Richards, G. Culture and Tourism-A Naturally Strengthening Connection? Presented at the Board Failte National Tourism Conference, Failte, Ireland. 2013. Available online: http:/ / www.failteireland.ie/FailteIreland/media/ WebsiteStructure/Documents/eZine/National-Tourism-Conference-2013-Greg-Richards.pdf (accessed on 15 March 2018).

48. United Nations Educational, Scientific and Cultural Organization (UNESCO). Sustainable Tourism Development in UNESCO. Designated Sites in South-Eastern Europe; Ecological Tourism in Europe-ETE: Bonn, Germany, 2009. Available online: http:/ / portal.unesco.org (accessed on 28 February 2018).

49. Erdoğan, E.; Erdoğan, H.A. An adaptive reuse experience for sustainable culture tourism: A case study on the historical texture of Sille/Turkey. In Proceedings of the 41st IAHS World Congress Sustainability and Innovation for the Future, Albufeira, Portugal, 13-16 September 2016.

50. Russo, A.P. The "vicious circle" of tourism development in heritage cities. Ann. Tour. Res. 2002, $29,165-182$. [CrossRef]

51. Sassen, S. Cities in a world economy. In Sociology for a New Century SERIES, 4th ed.; SAGE Publication, Pine Forge Press: Thousand Oaks, CA, USA, 2012; ISBN 978-1-4129-8803-2.

52. McIntyre, G. Sustainable Tourism Development: Guide for Local Planners; World Tourism Organization: Madrid, Spain, 1993.

53. Martin, B.S.; Uysal, M. An Examination of the Relationship between Carrying Capacity and the Tourism Lifecycle: Management and Policy Implications. J. Environ. Manag. 1990, 31, 327-333. [CrossRef]

54. Canestrelli, E.; Costa, P. Tourist Carrying Capacity: A Fuzzy Approach. Ann. Tour. Res. 1991, 18, $295-311$. [CrossRef]

55. Buckley, R. Ecological indicators of tourism impacts in parks. J. Ecotour. 2003, 2, 54-66. [CrossRef]

56. Taylor, J.P. Authenticity and sincerity in tourism. Ann. Tour. Res. 2001, 28, 7-26. [CrossRef]

57. Lindberg, K.; McCool, S.; Stankey, G. Rethinking carrying capacity. Ann. Tour. Res. 1997, 24, 461-465. [CrossRef]

58. Wall, G. Cycles and capacity: Incipient theory of conceptual contradiction? Tour. Manag. 1982, 3, $188-192$. [CrossRef]

59. Mccool, S.F.; Lime, D.W. Tourism Carrying Capacity: Tempting Fantasy or Useful Reality? J. Sustain. Tour. 2009, 9, 372-388. [CrossRef]

60. Zeayter, H.; Mansour, A.; Mansour, H. Heritage conservation ideologies analysis-Historic urban Landscape approach for a Mediterranean historic city case study. HBRC J. 2017. [CrossRef] 
61. Orbasli, A. Tourists in Historic Towns: Urban Conservation and Heritage Management; E \& FN Spon: London, UK, 2000; ISBN 0-419-25930-9.

62. Cuccia, T. Is it Worth Being Inscribed in the World Heritage List? A Case Study of "The Baroque Cities in Val di Noto" (Sicily). Rivista Italiana di Economia Demografia e Statistica 2012, LXVI, 169-190. [CrossRef]

63. Cuccia, T.; Guccio, C.; Rizzo, I. The Effects of UNESCO World Heritage List Inscription on Tourism, Destinations Performance in Italian Regions. Econ. Model. 2016, 53, 494-508. [CrossRef]

64. Cellini, R. Is UNESCO Recognition Effective in Fostering Tourism? A Comment on Yang, Lin and Han. Tour. Manag. 2011, 32, 452-454. [CrossRef]

65. Shirvani Dastgerdi, A.; De Luca, G. The Riddles of Historic Urban Quarters Inscription on the UNESCO World Heritage List. Archnet IJAR Int. J. Archit. Res. 2018, 12, 152-163. [CrossRef]

66. Poria, Y.; Reichel, A.; Cohen, R. Tourist Perceptions of World Heritage Site and Its Designation. Tour. Manag. 2013, 35, 272-274. [CrossRef]

67. Gonzalez Santa-Cruz, F.; Lopez-Guzman, T. Culture, Tourism and World Heritage Sites. Tour. Manag. Perspect. 2017, 24, 111-116. [CrossRef]

68. Di Matteo, D. Tourism performances, government effectiveness and local growth: The Italian cultural heritage perspective. In Routledge Handbook of Tourism Impacts: A Theoretical Perspective; Gursoy, D., Nunkoo, R., Eds.; Routledge: London, UK, 2018; accepted.

69. Falatooni, E.; Selen, W.; Kerr, D. A New Framework for Selecting Composite Indicators to Assess Sustainability of a Destination. Athens J. Tour. 2016, 3, 7-24.

70. Tanguay, G.A.; Rajaonson, J.; Therrien, M.C. Sustainable Tourism Indicators: Selection Criteria for Policy Implementation and Scientific Recognition. J. Sustain. Tour. 2013, 21, 862-879. [CrossRef]

71. Blancas, F.J.; Caballero, R.; González, M.; Lozano-Oyola, M.; Pérez, F. Goal programming synthetic indicators: An application for sustainable tourism in Andalusian coastal counties. Ecol. Econ. 2010, 69, 2158-2172. [CrossRef]

72. Blancas, F.J.; Lozano-Oyola, M.; González, M.; Guerrero, F.M.; Caballero, R. Science of the Total Environment How to use sustainability indicators for tourism planning: The case of rural tourism in Andalusia (Spain). Sci. Total Environ. 2011, 412-413, 28-45. [CrossRef] [PubMed]

73. Lozano-Oyola, M.; Blancas, F.J.; González, M.; Caballero, R. Sustainable tourism indicators as planning tools in cultural destinations. Ecol. Indic. 2012, 18, 659-675. [CrossRef]

74. Mikulic, J.; Kozic, I.; Kresic, D. Weighting indicators of tourism sustainability: A critical note. Ecol. Indic. 2015, 48, 312-314. [CrossRef]

75. Gallego Carrera, D.; Mack, A. Sustainability assessment of energy technologies via social indicators: Results of a survey among European energy experts. Energy Policy 2010, 38, 1030-1039. [CrossRef]

76. Mathew, P.V.; Sreejesh, S. Impact of responsible tourism on destination sustainability and quality of life of community in tourism destinations. J. Hosp. Tour. Manag. J. 2017, 31, 83-89. [CrossRef]

77. Lee, T.H.; Hsieh, H. Indicators of sustainable tourism: A case study from a Taiwan's wetland. Ecol. Indic. 2016, 67, 779-787. [CrossRef]

78. Moldan, B.; Janousková, S.; Hák, T. How to understand and measure environmental sustainability: Indicators and targets. Ecol. Indic. 2012, 17, 4-13. [CrossRef]

79. Kloos, M. Heritage Impact Assessment as a tool to open up perspectives for sustainability: Three case studies related to discussions concerning the visual integrity of World Heritage Cultural and Urban Landscapes. In Perceptions of Sustainability in Heritage Studies; Marie-Theres, A., Ed.; De Gruyter: Berlin, Germany, 2015; pp. 215-228. [CrossRef]

80. Seyedashrafi, B.; Ravankhah, M.; Weidner, S.; Schmidt, M. Applying Heritage Impact Assessment to urban development: World Heritage property of Masjed-e Jame of Isfahan in Iran. Sustain. Cities Soc. 2017, 31, 213-224. [CrossRef]

81. International Council on Monuments and Site (ICOMOS). Guidance on Heritage Impact Assessments for Cultural World Heritage Properties; International Council on Monuments and Site: Paris, France, 2011. Available online: www.icomos.org (accessed on 6 April 2018).

82. Sagnia, B.K. Cultural Impact Assessment Project. Framework for Cultural Impact Assessment. Dakar: International Network for Cultural Diversity (INCD). 2004. Available online: http:/ / www.dmeforpeace.org (accessed on 6 April 2018). 
83. Drdácký, M.; Drdácký, T. Risks Generated by Tourism in an Environment with Cultural Heritage Assets. International Preservation News-Tourism and Preservation: Some Challenges. 2010. Available online: www.ifla.org/files/assets/pac/ipn/52-december-2010.pdf (accessed on 2 May 2018).

84. Sofianou, E.; Bayouk, S. Perspectives for sustainable built heritage and urban regeneration towards cultural tourism development: A case study from Northern Greece. In Proceedings of the 54éme Colloque ASRDLF-15th Conference ERSA-GR, Les Défis de Développement Pour les Villes et Les Régions Dans une Europe en Mutation, Athens, Greece, 5-7 July 2017.

85. Wang, X.; Wang, J.; Wennersten, R. Strategic Urban Design from a Sustainable Tourism Perspective: A Case Study from the City of Guangzhou, China. In The Sustainable City, Proceedings of the 4th International Conference on Urban Regeneration and Sustainability, Tallin, Estonia, 17-19 July 2006; Mander, U., Brebbia, C.A., Tiezzi, E., Eds.; WIT Press: Gateshead, UK, 2006; pp. 333-342.

86. Ponticelli, L. Modelli Valutativi per i Processi di Coordinamento delle Politiche Territoriali. 2014. Available online: www.dolomitiunesco.info/?pubblicazioni=dalla-carrying-capacity-alla-carryingcapability (accessed on 2 May 2018).

87. Berardi, S.; Minuti, M.S.; Desinano, P. Lo Sviluppo Turistico nei Siti del Patrimonio UNESCO-Principali Caratteristiche e Trasformazioni Indotte. 2013. Available online: http:/ /www.sitiunesco.it/wp-content/ uploads/2015/05/PDFIASSISI.pdf (accessed on 2 May 2018).

88. Insights-Round Table on Sustainable Urban Tourism. Madrid, Spain, 2017. Available online: http:// historicalcity.eu/wp-content/uploads/2018/01/insights_round_table.pdf (accessed on 2 May 2018).

89. Yildirim, M.; Turan, G. Sustainable Development in Historic Areas: Adaptive Re-Use Challenges in Traditional Houses in Sanliurfa, Turkey. Habitat Int. 2012, 36, 493-503. [CrossRef]

90. Yildiz, S.; Polatoglu, C. Evaluating the built environment in the context of barrier free tourism, a case study in Istanbul. In Proceedings of the 2nd International Scientific Conference Tourism in South East Europe 2013, Opatija, Croatia, 15-18 May 2013; pp. 435-446.

91. Ariffin, A.B.; Zahari, M.S.M.; Radzi, S.M.; Kutut, M.Z. Adaptive Reuse of Historical Buildings and Local Residents' Actual Visitation. J. Tour. Hosp. Culin. Arts 2017, 9, 35-46.

92. Hasnain, H.; Mohseni, F. Creative ideation and adaptive reuse: A solution to sustainable urban heritage conservation. In Friendly City 4 from Research to Implementation for Better Sustainability; IOP Conference Series: Earth and Environmental Science; IOP Publishing Ltd.: Bristol, UK, 2018; Volume 126. [CrossRef]

93. Plevoetz, B.; Van Cleempoel, K. Adaptive reuse as an emerging discipline: An historic survey. In Reinventing Architecture and Interiors: A Socio-Political View on Building Adaptation; Libri Publishers: London, UK, 2013; pp. 13-32.

94. Ijla, A.; Brostrom, T. The Sustainable Viability of Adaptive Reuse of Historic Buildings: The Experiences of Two World Heritage Old Cities; Bethlehem in Palestine and Visby in Sweden. Int. Invent. J. Arts Soc. Sci. 2015, 2, 52-66.

95. Lerario, A.; Maiellaro, N.; Zonno, M. Remote fruition of architectures: R\&D and training experiences. In Proceedings of the Second International Conference on Advances in Multimedia, Athens, Greece, 13-19 June 2010; IEEE Computer Society: Washington, DC, USA, 2010. [CrossRef]

96. Brooker, G.; Stone, S. Context \& Environment; Series "Basics Interior Architecture"; AVA Publishing: Lausanne, Switzerland, 2008; ISBN 9782940373710.

97. Miralles, J.L.; Garcia-Ayllon, S. GIS Analysis of the Consequences of Short-Term Urban Planning in a Mass Tourism Destination in Spain. Int. J. Sustain. Dev. Plan. 2015, 10, 499-519. [CrossRef]

98. Samat, N.; Harun, N. Urban Development Pressure: Challenges in Ensuring Sustainable Tourism Development in Langkawi Island. Procedia Soc. Behav. Sci. 2013, 91, 385-394. [CrossRef]

99. Bhavya Sree, D.; Chandrakanth, N. A Survey on Urban Tourism Development and Its Characteristics. IJARIIT Int. J. Adv. Res. Ideas Innov. Technol. 2017, 3, 616-620.

100. Chen, L.; Thapa, B.; Kim, J.; Yi, L. Landscape Optimization in a Highly Urbanized Tourism Destination: An integrated Approach in Nanjing, China. Sustainability 2017, 9, 2364. [CrossRef]

101. Encalada, L.; Ferreira, C.C.; Rocha, J.; Boavida-Portugal, I. Geographical patterns in the tourist city: GIS for spatiotemporal analysis. In GIS Applications in the Tourism and Hospitality Industry; Chaudhur, S., Ray, N., Eds.; IGI Global: Hershey, PA, USA, 2018; pp. 76-97, ISBN 9781522550884. 
102. Ritchies, J.R.B.; Crouch, G.I. The Competitive Destination-A Sustainable Tourism Perspective; CABI Publishing: Wallingford, UK, 2003; ISBN 0-85199-664-7.

103. Misrahi, T. Wish You Weren't Here: What Can We Do About Over-Tourism? World Economic Forum LLC: New York, NY, USA, 2017. Available online: https:/ /www.weforum.org/agenda/2017/09/what-can-wedo-about-overtourism/ (accessed on 5 June 2018).

(c) 